European journal of American studies

\title{
A Trustworthy Collaboration: Eleanor Roosevelt and Martha Graham's Pioneering of American Cultural Diplomacy
}

Camelia Lenart

\section{CpenEdition}

\section{Journals}

Electronic version

URL: https://journals.openedition.org/ejas/11972

DOI: 10.4000/ejas.11972

ISSN: 1991-9336

Publisher

European Association for American Studies

Electronic reference

Camelia Lenart, "A Trustworthy Collaboration: Eleanor Roosevelt and Martha Graham's Pioneering of American Cultural Diplomacy", European journal of American studies [Online], 12-1 | 2017, document 5, Online since 16 March 2017, connection on 08 July 2021. URL: http://journals.openedition.org/ejas/ 11972 ; DOI: https://doi.org/10.4000/ejas. 11972

This text was automatically generated on 8 July 2021

Creative Commons License 


\title{
A Trustworthy Collaboration: Eleanor Roosevelt and Martha Graham's Pioneering of American Cultural Diplomacy
}

\author{
Camelia Lenart
}

1 Shortly after FDR's first inauguration Eleanor Roosevelt declared in an interview that all what she wanted was to remain "plain Eleanor Roosevelt, not the First Lady," and to be useful. ${ }^{i}$ Her activity during the White House years, as well as after them, proved that she achieved her goal of being useful to many causes and people, but not the one of being plain. Much is known and researched about ER's activity in areas such asfeminism, civil and human rights, containment, and nuclear disarmament, while her complex and full life, her persona and emotional imbroglios were also closely deciphered and analyzed. However, ER's role as a pioneer of American cultural diplomacy, and the way in which she innovatively created its foundation still needs to be established and explored. ER was one of the first American personalities who understood the necessity of using the "soft power" of arts in politics and diplomacy: she lobbied for federal support of the arts and created the path on which American cultural diplomacy would develop until its official inception in 1954.

2 It was a very important endeavor and legacy of Eleanor Roosevelt, as unlike the French, Germans and Italians who had pursued cultural diplomacy since before 1914, and the Soviets who created a "Society for Cultural Relations with Foreign Nations" in 1925, America did not have an active cultural diplomacy.iihat complicated the situation even more was that the American puritanical foundation iii and its "absorption in economic development" ${ }^{\text {"iv }}$ created a society rather indifferent to the arts. Thus, not only American state patronage of the arts was lacking, but also, unlike in most Western countries, the arts' patronage by individuals was minimal..$^{v}$ When arts' patronage started to develop, mostly after the beginning of the $20^{\text {th }}$ century, there were the American women, such as Isabella Gardner Stewart, Mabel Dodge Luhan, Peggy 
Guggenheim, who were most visibly and actively involved in this activity. ${ }^{\mathrm{v} I}$ Invited by the First Lady, Martha Graham performed at the White House some of her Americana pieces in 1937, during the intricate years of the American neutrality, preceding USA's entry into the war. Eleanor Roosevelt's vision of supporting the arts but also of making them an agent of political and diplomatic power was essential in the context of the Cold War and of the competition with Soviet Union. Following in her footsteps, the American politicians understood the power of the non-verbial language of dance to penetrate barriers and express political messages subliminally, thus "avant-garde" dancers such as Martha Graham were sent abroad as cultural diplomats. vii They had to prove the quality of American culture and American freedom, ${ }^{\text {viii }}$ that America was more than a "ballet nation," ix but also to demonstrate that American dancers could equal and even surpass the "Swans of Kremlin's" innovation, quality, and artistry in dance. ${ }^{x}$

3 The choice of Martha Graham to represent the USA as a cultural diplomat was not coincidental. Besides being an American icon, Graham already toured Europe in 1950 and during the early 1954, prior to President Eisenhower's establishment of the Emergency Fund for International Affairs to support cultural presentations abroad. ${ }^{\mathrm{xi}}$ Her performances, endorsed and helped by Eleanor Roosevelt, constituted a useful "rehearsal" of the American cultural diplomacy "offer" on the continent, while the exposure to - and practice of - politics in Graham's earlier tours to Europe contributed to her "eligibility" for performing arts and politics in the complicated space beyond the Iron Curtain. In 1962, during the State Department tour in 1962, the famous American modern dancer would tour the communist countries Yugoslavia and Poland. ${ }^{\text {ii }}$

4 ER's determination and ability in using art for making political statements is most discussed in the context of Marion Anderson, the African-American opera singer who was banned in 1939 by the Daughters of the American Revolution from performing in its Washington concert hall due to her race. ER, known for her anti-racism and determination to participate in solving the racial problems of the USA, resigned from the DAR organization, and afterward helped with Anderson's concert in front of the Lincoln Memorial on Easter Sunday April 9, 1939, before an integrated audience. Anderson's interpretation of "My country, 'tis of thee, Sweet land of liberty" was a historic event, which exceeded the cultural boundaries, and carried political and social statements of major significances. ER's association with Marian Anderson, and the role she played in the event were also a clear statement of the First Lady's Civil Rights stance. Less is known and researched about another artist's performance initiated and supported by the First Lady. On February 26, 1937, two years before Marian Anderson's memorable concert, Martha Graham was "the first dancer ever asked to perform at the White House."xiii Taking place during a sensitive historical time due to the European political developments of the thirties, and having the President in attendance, Graham's performance marked the beginning of the collaboration between Eleanor Roosevelt and the famous dancer. ${ }^{\text {xiv }}$

5 Analyzing the collaboration between the First Lady of the White House and the First Lady of Dance is fascinating because it would be hard to find two persons and personalities, who, apparently, had less in common. The physical appearance of the tall, and not particularly sophisticated ER, was in sharp contrast with the petite and dramatic appearance of Martha Graham. While ER was the indefatigable humanitarian of her country and of the world during difficult times, approachable and warm, Martha 
Graham was the creator who navigated mostly in her selected artistic circles, dedicated herself to art, and was perceived mostly as distant and self-involved. But behind and beyond all this, both women were history makers, who offered humanity their exceptional best, and whose lives intersected in the field of American cultural diplomacy. ${ }^{\mathrm{xv}}$

6 ER's interest in the link between arts and politics can be traced back to her school years at Allenswood, in England. There she was influenced by its Headmistress, Mlle Marie Souvestre, who infused her students with the responsibility she had towards others and in bettering the world around her, and revealed to them the possibility of using the arts in the service of politics. ${ }^{\text {xvi }}$ The First Lady, who felt strongly that American society had not done enough for the arts, became a supporter of them since her husband's first mandate. The gesture was even more commendable as FDR did not have the arts on his list of priorities, and he was very cautious when it came to supporting them. ${ }^{\text {xvi }}$ ER was a key advocate for the creation and development of "Federal One" (Federal Project Number One) in 1935, which was constructed as a subdivision of the Works Progress Administration (WPA,) and which sought to extend the relief of the New Deal to artists, actors, writers, and musicians. ${ }^{\text {xviii }}$ ER was also the one who encouraged Henry Hopkins, more than the President, to continue with the project supposed to support "thousands of artists, musicians, actors, and writers." xix

7 Federal One became a powerful tool for infusing art and culture into the daily lives of Americans, and ER was delighted in the artistic work crafted with federal dollars. Her commitment to this project was total, praising it in her columns and speeches, and defending it against congressional critics. ${ }^{x x}$ She was particularly interested in the Dance Project, most active in Chicago and New York, where people from the dance milieu such as Doris Humphrey, Charles Weidman, Ruth Page, and some of Graham's dancers gave WPA-supported concerts. ${ }^{x \times i}$ The involvement of ER in the arts' patronage during the Depression created the image of the First Lady as a patron of the arts and associated her with the idea of State patronage. The number of letters received by ER from artists increased in an impressive way during the thirties, with a large part of the correspondence coming from the African-Americans. Due to her "wide vision" in this field, xxii "interest in contemporary art," and her "very forward and progressive policy in the arts,"xxii the senders were regarding the First Lady as the country's most important and reliable arts' protector. Dina Huebert of California, who was hoping to perform at the White House her "contemporary dances with American themes," went even further, claiming that American art patronage was "synonymous with her (ER) name." $x x i v$ The role of ER as the patron of the arts was proven even more on the occasion of the visit by Britain's King George VI his wife to the United States. ${ }^{\mathrm{xx}}$ The letters and messages received by ER from artists ready to perform for the royal guests tripled, even if it was widely known that the events and the programs at the WH were arranged by Henry Junge, Steinway and Sons. For Americans, the First Lady was becoming the most respected maker of the cultural image of their country, inside and out, while her involvement in the arts gave ER the opportunity to meet some of the most innovative American artists of the moment. Martha Graham was the right person at the right time in this endeavor, and her art was also able to convey the political message Eleanor Roosevelt believed in.

8 The two women met in 1936 through Rita Morgenthau (the sister-in-law of Henry Morgenthau, the Secretary of the Treasury under the Roosevelt administration,) at 
Neighborhood Playhouse. The occasion was a fundraising demonstration for the cause of the Civil War in Spain, in which the First Lady was very interested, as demonstrated by the correspondence with Martha Gelhorn. xxvi Graham was also teaching dance at the "School for Arts Related to the Theater" associated with Neighborhood Playhouse, and also performed during that evening. The next day, the dancer's press agent and manager Frances Hawkins sent Roosevelt a letter and a souvenir booklet. ${ }^{x x v i i}$ On December 20,1936, Chronicle - an essential Graham work which openly opposed the war in Spain - was presented to the public at Guild Theater in New York, and the First Lady received an invitation and tickets. ${ }^{x x v i i i}$ She did not honor the invitation, but very shortly after she requested Martha Graham to present "a few dances" at the White House, on the occasion of a birthday party for Elinor Morgenthau, the wife of Henry Morgenthau Jr. and one of ER's closest friends. ER also invited Graham and her party to spend the night at the White House, which they gracefully declined. Louis Horst, Graham's longtime friend, companion, and collaborator (supposed to have shared the room with Elliott Roosevelt) recounted the night to Agnes de Mille, peppering it with anecdotes, suggesting the well-known First Lady's lack of formality in hosting people and in creating the menu of the White House.xxix ER recalled Graham's invitation in the "My Day" column on March 1, 1937:

9 "Sunday-Friday night, Miss Martha Graham of New York came down and danced for us after dinner. I asked her afterwards if it did not require the most tremendous amount of training to keep her body under such perfect control and she told me she had to work four hours every day, and that if she took six weeks off in summer it took her two months to regain what she had temporarily lost. How few of us realize when we watch a performance that what may interest us for a short time requires so much hard work and devotion on the part of the artist." ${ }_{\mathrm{xxx}}$

10 However, ER's admiration as well as the reasons for the invitation went beyond the sole artistic qualities of the American dancer and choreographer. As in Anderson's case, the invitation was not the result of a spur of the moment idea or mere a social event, but one during which the First Lady also connected arts, politics, and expressed her political views through the soft power of the arts. The First Lady was aware of the Nazis' aggressive politics and discriminations, and believed in her country's role in saving the world from a terrible fate. ${ }^{\mathrm{xxi}}$ In a letter sent to Elinor Morgenthau , - whom ER "prized most highly" for her friendship and commitment xxxii to the causes on they which worked together, - she shared the anguish over the Nazi's rise to power in Europe and America's involvement in a possible war. ${ }^{x x i i i}$ She confessed that "the horrible German news" made her believe even more strongly that "if we remain neutral we will suffer in the end. It makes me sick." xxxiv

11 By the time she was invited to the White House, Martha Graham's art and persona were the Americana portrayal of the country's prides, successes and challenges. Graham, a proud sixth-generation American with a line of Scotch-Irish ancestors which included Myles Standish, the English military officer who accompanied the Pilgrims on their journey on the Mayflower, developed her art innovation outside of the European influences, and aimed to create an "art of and from America." ${ }_{x x x v}$ In 1932 Graham was awarded a Guggenheim Memorial fellowship; she used it in order "to create something American," and declined the modern dancer Mary Wigman's offer to study with her in Germany. ${ }^{x x x v i}$ During late 1935 Graham received an invitation, from the Reichminister of Volksaufklarung unt Propaganda, Dr. Joseph Goebbels, to perform at the 
International Arts Festival organized in conjunction with the Olympic Games in Berlin. ${ }^{\text {xxvii }}$ Graham refused, openly stating her disapproval of the Nazi treatment of Jewish people and the persecution of Jewish artists, ${ }^{\text {xxxiii }}$ a gesture which was commented by numerous American newspapers, including New York Times ${ }^{\mathrm{xxx} x}$ and Dance Observer. ${ }^{\mathrm{xl}}$

12 Besides, Graham was at the peak of her Americana phase, creating dances focusing on American history, and her choreography, which until then was mostly viewed as "too modern and grim," was now considered "devotedly patriotic."xli With an artistic practice deeply ingrained in the rhythm of American life, Graham's dances brought a distinctly American sensibility to every theme she explored. "A dance reveals the spirit of the country in which it takes root," she wrote in her 1937 essay "A Platform for the American Dance."xliiBetween 1934 and 1936, Graham created American Provincials, which "unsentimentally portrays the religion-frenzied Puritan and the mockery of her Philistine neighbors,"xliii Frontier,"a symbol of a (the Americans') journey into the unknown, and American Lyric "with its theme as the basic American right-freedom of assembly." "xliv As mentioned, in 1936 she created Chronicle, while the year after Graham's performance at the White House, she created Immediate Tragedy, Deep Song, also inspired by the Spanish Civil War. ${ }^{x l v}$ In August 1938, just a year before the beginning of the Second World War, Graham created the masterpiece of her Americana works, American Document, "an experimental work which used the Declaration of Independence and the Emancipation Proclamation among its spoken texts." "xlvi

13 The end of the Second World War was a special time for ER, whose White House Years came to an end. She was conscious that for those "who lived in his (FDR) shadow" it was the time to "start under our own momentum and wonder what we can achieve."xlvii The former First Lady continued to commit herself to the causes she believed in previously, including the one of cultural diplomacy, and to supporting artists such as Graham, with whom she "became good friends in the 1940s, attending meetings together and riding in the same car." $x$ lviii

14 The Americans, who continued to be regarded by Europeans as "culturally barren," did not yet have a well-organized cultural diplomacy, problem which was becoming crucial during the Cold War's competition. ${ }^{\text {xlix }}$ Unlike in the Soviet Union, where the culture was heavily sponsored by the State, and where "a Soviet ballerina or a premier dancer carried travel permits equal to those of an army general," in the United States the arts were still seen as a luxury. ${ }^{1}$ The (un)importance of American cultural diplomacy, which had many opponents, ${ }^{1 i}$ was a subject of debate in Congress. ${ }^{\text {lii }}$ However, even those who agreed with the idea of cultural diplomacy, stressed that the task of it was, "to sell US to the world just as a sales manager's job is to sell a Buick or a Cadillac or a radio or a TV set," "liii and that true American-ness should be shown abroad through "serious arts" and not by any means through modern dance. Only some preeminent Americans, like Eleanor Roosevelt and later on Dwight D. Eisenhower, agreed that Benjamin Disraeli's idea that "a book may be as great a thing as a battle," liv was still valuable in the new political context. The former First Lady and the new president were convinced the Americans could win the competition of the Cold War over "the human soul, the human heart, and the human mind" with the help of cultural diplomacy, and by controversial arts, such as modern dance..$^{\mathrm{lv}}$

15 At the end of June 1950, Eleanor Roosevelt's column "My Day" informed the readers about her participation in the Security Council's meetings in Paris, which was 
discussing some the problems of the "deeply agitated" postwar world. The former First Lady, now an accomplished politician of her own, also reflected on human nature, which was making people continue "their daily lives and do the things they planned to do" in spite of their worries. In her case, it meant seeing the Cathedral of Chartes, and watching the American dancer Martha Graham's opening night "with Ambassador and Mrs. Bruce," which she considered " a most interesting performance and one which met with warm approval of the French audience, which is, at all times, an honest and critical one." The French journals did not fail to notice their presence: Paris Presse reminded the readers that the former First Lady had applauded the dancer first at the White House in 1937, lvi while Le Parisien Libre commentedthat Graham was greatly admired by her compatriots, this explaining the presence of Eleanor Roosevelt and Mrs. Bruce at her performance in Paris. ${ }^{\text {Ivii }}$

16For some in the audience of the Theatre des Champs-Élysées, ER's presence at Graham's performance on June 27, 1950, when "Martha Graham and her Company made a bow to Paris," might have looked as just a gesture of support from one "American in Paris" to another. For those aware of ER's involvement in the complicated mélange of American arts and politics since the 1930s, her presence at Graham's performance had political and diplomatic connotations. The assumption was supported by ER's own statement which suggested that it was a "planned" appearance and by the presence in the center box of the American Ambassador in France David K. E. Bruce and his wife. lviii The American Ambassador's presence at Graham's performance also had special significance, as before Graham's tour he warned Dean Acheson, the Secretary of State in Washington about the complications which the American artists, including Graham, could encounter in Paris, where American artists were often treated with hostility. lix $\mathrm{He}$ also believed that the French impresario Anatole Heller, supposed to represent the American companies, was "unscrupulous and bungling," thus suggesting that his role should be restricted and minimized. Most importantly, while emphasizing that even "high French officials" recognized the dangers, Bruce concluded his warnings to the Secretary of State that all these factors could negatively affect "Franco-American cultural relations." "Ix To all these comments, Dean Acheson responded promptly and advised utmost care and "soonest completion."

17 The "endorsement" of American artists touring abroad by their country's politicians was one of the characteristics of American cultural diplomacy before its official inception in 1954. During the early fifties, while designing its "grand cultural strategy" and trying to catch up with the progress of other countries in this field, American cultural diplomacy went through a "rehearsal" period when top American officials endorsed, supervised, intervened, and helped from behind the stage their cultural diplomats in the making. Beside Graham and other modern dancers, American ballet companies, jazz musicians, symphonic orchestras, and expressionist painters toured Europe. Most of them had private sponsorship (among others, Bethsabee de Rothschild and Lilla Acheson in Graham's case, and Peggy Guggenheim in Pollock's), but they also received logistic support from the State Department and the American Embassies abroad. ${ }^{\text {lxii }}$ However, ER had practiced the "endorsement" of American artists - for outspoken political reasons - since the thirties. When Graham was invited to the White House, she was told that "there will be some people here who will be well worthwhile meeting," and also that the White House was ready "to give some publicity for your appearances," thus suggesting that the invitation to the White House was already an "endorsement" of Graham. ${ }^{\text {.xii }}$ By 1950 ER was even more aware that helping 
American artists was important, as during the early fifties "what Western Europe had lost in political power and political prestige it was now making up for in the arts," antiAmericanism was on the rise, affecting not only the presence of the American artists touring abroad but also American political interests in the area. ${ }^{\text {kiv }}$ The situation was most complicated in France, especially in Paris, where there was an extra-sensitivity related to the radical changes of the postwar years, which were affecting the country's and city's cultural hegemony, in favor of the USA and New-York. ${ }^{1 \times v}$ The same day as Graham's performance, ER also visited the studio of Jo Davidson, lxvi the American sculptor acclaimed for his works on political personalities, including FDR and Harry Hopkins, and the bronze busts of the leaders of the First World War Allies. ${ }^{\text {xvii }}$

${ }_{18}$ ER's resourcefulness in supporting and endorsing American art, artists, and cultural diplomacy was exemplary. Over the years, when royals and important heads of states were the guests of the Roosevelts, artists such as Marian Anderson - who was introduced to the British Royals in 1938 - were invited to meet them. ${ }^{\text {lxviii }}$ "The most famous Dutch-Americans in the White House" developed a close friendship with the Dutch Queen Wilhelmina and her daughter Juliana since 1941, when the latter lived in exile in Lee, Massachusetts. Juliana would become the Queen of the Netherlands in 1948 , , lix the year when ER visited her, when she went to the Netherlands to receive a doctorate in law from the University of Utrecht. The former First Lady saw Juliana for the second time in 1951, ${ }^{1 \times x}$ while Juliana and her husband paid an unofficial visit to ER in Hyde Park, during their American tour in 1952. ${ }^{1 \times x i}$ On April 9, 1952, the Royal couple accompanied the former First Lady to New York, where they spent a day without official engagements. In the evening they went on Broadway to see the musical "The King and I," on which occasion, along with other famous people of American arts and culture, they met Martha Graham. ${ }^{\text {.xxii }}$

19 In 1954, on the occasion of Graham's performance in The Hague, Queen Juliana and Princess Irene of the Netherlands were in the audience. As shown by a photograph never discussed so far, taken from a private collection, the Queen and the young princess are shown greeting Martha Graham in front of her dressing room. Graham, who was wearing her Chinese robe, with a bandana tying her hair, looked comfortable and also content next to the royal guests. ${ }^{\text {lxxiii }}$ The momentum was a very special one, as the presence of royals at Graham's performance in Europe was an unprecedented success for the dancer, but also for American diplomacy in Europe.

20 In spite of her desire to be "just" Eleanor Roosevelt, over the years ER became a skilled politician, who had a special talent and ability to seize an opportunity and use it for her causes. She invited Martha Graham to perform at the White House when the USA was contemplating its entrance in the Second World War. During the early fifties, the former First Lady, now a recognized politician and savvy diplomat on her own, used her prestige and connections in helping Graham during her tours in Europe. Accompanied by the American Ambassador David Bruce, Roosevelt attended Graham's opening night in Paris, during the dancer's difficult first European tour in 1950. When Queen Juliana of the Netherlands visited Hyde Park in 1952, she orchestrated the Queen's meeting with Graham in New York City, thus, on the occasion of Graham's second European tour, in 1954, the Queen attended the American dancer's performance.

21 Debuted and developed during a time when Americans did not believe (yet) in the power of the arts in making and un-making political and diplomatic statements, ER's 
trustworthy relationship with Martha Graham demonstrated the innovative and intricate way in which ER used arts in the service of politics, and her role in the creation of American cultural diplomacy. By the time of ER's death, in November 1962, Martha Graham, the pioneer of modern dance, was at the peak of her role as a cultural diplomat, and was about to perform beyond the Iron Curtain, on her first State Department tour to Europe. ${ }^{\text {Ixxiv }}$ Her international tours, incepted with the 1950 performance in Paris attended by the former First Lady, proved that Americans could create world famous art, and also that, as Eleanor Roosevelt, the pioneer of the American cultural diplomacy envisioned, the "soft power" of the arts was an essential component of diplomacy and politics.

\section{NOTES}

i. Jacobs, William Jay. Eleanor Roosevelt: A Life of Happiness and Tears (New York: Coward-McCann, 1983), p. 69.

ii. Tony Judt, Postwar: A History of Europe Since 1945(London: Penguin, 2006), p. 33.

iii. Ibidem.

iv. Julia Margartet Carson, Mary Cassatt (New York: D. McKay Co,1966), p. 6.

v. Alexander, Holmes, "American Arts and Patronage," in College and University Journal, vol. 10, no. 3, 1971, p. 20-23.

vi. See Whitney Chadwick, Women, Arts and Society ( New York: Thames and Hudson, 2012), p. 322; Louise Hall Tharp, Mrs. Jack: A Biography of Isabella Stewart Gardner (New-York: Congdon \& Weed, 1984); Lois Palken Rudnick, Mabel Dodge Luhan: New Woman,New World (Albuquerque :University of New Mexico Press, 1987);Peggy Guggenheim, Out of This Century: Confessions of an Art Addict ( New York: Bookthrift Co, 1982.)

vii. Camelia Lenart, "Rehearsing and Transforming Cultural Diplomacy: Martha Graham's Tours to Europe during the Fifties," published in the Proceedings of Dance History Scholars Conference, October 2013.

viii. Naima Prevots, Dance for Export (Middletown: Wesleyan University Press, 2001), p. 3.

ix. Clare Croft, Dancers as Diplomats: American Choreography in Cultural Exchange(New York: Oxford University Press, 2015), p. 35.

x. Christina Ezrahi, Swans of the Kremlin. Ballet and Power in Soviet Russia (Pittsburg: University of Pittsburgh, 2012), p. 4.

xi. https://www.loc.gov/exhibits/hope-for-america/cultural-diplomacy.html; accessed October 2016.

xii. Camelia Lenart, "Dancing Art and Politics Beyond the Iron Curtain: Martha Graham's 1962 Tour to Yugoslavia and Poland," Dance Chronicle,vol. 39, no. 2, 2016, p. 197-217.

xiii. Don McDonagh, Martha Graham: A Biography (New York, Praeger, 1973), p. 232.

xiv. Franklin Delano Roosevelt, "Day by Day" http://www.fdrlibrary.marist.edu/daybyday/ daylog/february-26th-1937; accessed December 2015.

xv. The artist would also give up her membership to the DAR after they stopped Marian Anderson from singing. Martha Graham, Blood Memory (New York: Doubleday, 1991), p. 153.

xvi. William Jay Jacobs, Eleanor Roosevelt. A Life of Happiness and Tears (New York: Coward-McCann, 1983), p. 26-27. 
xvii. Marjorie Garber, Patronizing the Arts, Princeton University Press (August 17, 2008), p. 65.

xviii. Karen Bel-Kanner, Frontiers: The Life and Times of Bonnie Bird. American Modern Dancer and Dance Educator (London: Harwood Academic Publishers, 1998), p. 185-186.

xix. David M. Kennedy, Freedom from Fear. The American People in Depression and War, 1929-1945, (Oxford \& New York: Oxford University Press,) p. 254.

xx. Read more: http://www.notablebiographies.com/Ro-Sc/RooseveltEleanor.html\#ixzz3qBcqPuA9; accessed December 2015.

xxi. Karen Bel-Kanner, Frontiers: The Life and Times of Bonnie Bird. American Modern Dancer and Dance Educator (London: Harwood Academic Publishers, 1998), p. 186; Interestingly, Paige and Graham would tour France in 1950, and both would be helped by the American Embassy in Paris while there (Letter from the Cultural Relations Department to the US Embassy in Paris, 10 May 1950, Minister des Relations Exterieures, R.C. 1948-1955, Serie II, Echanges Culturelles, Etats -Unis , Archives des Affaires étrangères (Archives diplomatiques), La Courneuve, France.)

xxii. Letter to ER from Genevieve Jones, August 16, 1939, Box 440, Paper Events, Eleanor Roosevelt Papers, WH Correspondence, 1933-1946, Presidential Library, Hyde Park.

xxiii. Letter to ER from Dina Huebert, June 19, 1939, Box 440, Paper Events, Eleanor Roosevelt Papers, WH Correspondence, 1933-1946, Presidential Library, Hyde Park.

xxiv. Ibidem.

xxv. Eleanor Roosevelt, The Autobiography of Eleanor Roosevelt (New York: Da Capo, 1992), p. 199.

xxvi. Blanche Wiesen Cook, Eleanor Roosevelt, Volume Two, 1933-1938 (New York: Viking Press, 1999), p. 455.

xxvii. Don McDonagh, Martha Graham: A Biography, (New York, Praeger, 1973), p. 116-117.

xxviii. Ibidem, p.119.

xxix. Agnes DeMille, Martha. The Life and work of Martha Graham (New York, First Vintage Books Edition, 1992), p. 221-222.

xxx. "My Day" March 1, 1937, https://www.gwu.edu/ erpapers/myday/browsebyyear.cfm; accessed March 2016.

xxxi. David M. Kennedy, Freedom from Fear. The American People in Depression and War, 1929-1945, (Oxford \& New York: Oxford University Press.)

xxxii. Eleanor Roosevelt, The Autobiography of Eleanor Roosevelt (New York: Da Capo, 1992), p. 123. xxxiii. Their collaboration was described in detail by the former First Lady in her autobiography: they worked together on the Democratic State Committee in 1928 (p. 148), the WPA projects (p. 176), while Morgenthau was her assistant in the Office of Civilian Defense (p. 225-229.)

xxxiv. Blanche Wiesen Cook, Eleanor Roosevelt, Volume Two, 1933-1938 (New York: Viking Press, 1999), p. 283; ER's implication in the problem of the possible war and of the American participation in it was described in detail in the chapter "Mobilizing for New Action" and "A Silence Beyond Repair."

xxxv. Julia Lawrence Foulkes, "Dancing America: Modern dance and cultural nationalism, 1925-1950," PhD Thesis, University of Amherst, 1997, p. 3.

xxxvi. Ramsay Burt, Alien Bodies: Representations of Modernity, "Race," and Nation in Early Modern Dance (London: Routledge, 1998), p. 132.

xxxvii. Don McDonagh, Martha Graham, p. 113.

xxxviii. Agnes DeMille, Martha. The Life and work of Martha Graham, p. 223.

xxxix. "German Invitation Refused by Dancer," New York Times, March 13, 1936.

xl. "Olympic Protest," Dance Observer, April, 1936.

xli. Maureen Needham Costonis, "Martha Graham's American Document: A Minstrel Show in Modern Dance Dress," in American Music, vol. 9, no. 3, 1991, p. 297-310.

xlii. Maureen Nedham, I See America Dancing: Selected Readings, 1685-2000 (University of Illinois Press, 2002), p. 176. 
xliii. Program, Martha Graham, Guild Theatre, November 10, 1935, Box 31, Martha Graham Collection Box 311, Music Division, Library of Congress.

xliv. Program, Martha Graham and Dance Group, Mount Holyoke College, October 27, 1938, Martha Graham Collection Box 314, Music Division, Library of Congress.

xlv. Anna Kisselgoff, "Dance view: Graham's Deep Song: 51 and Still Protesting," in New York Times, October 16, 1988; in 1937 these were only two among many solos created by other dancers and choreographers in sympathy with the suffering in Spain. Titles like Jose Limon's "Danza de la Muerte," Lily Mehlman's "Spanish Woman" and Sophia Delza's "We Weep for Spain."

xlvi. Maureen Needham Costonis, "Martha Graham's American Document: A Minstrel Show in Modern Dance Dress," in American Music, vol. 9, no. 3, 1991, p. 297-310.

xlvii. Letter from Eleanor Roosevelt to Lorena Hickok, April 19, 1945, in Allida M. Black, Casting her Own Shadow. Eleanor Roosevelt and the Shaping of Postwar Liberalism (New York: Columbia University Press, 1996).

xlviii. Martha Graham, Blood Memory (New York: Doubleday, 1991), p. 153.

xlix. Frances Stonor Saunders, The Cultural Cold War (New York: The New Press, 2000), p. 19.

1. Walter Terry, Frontiers of Dance. The Life of Martha Graham (New York: Thomas Y. Cromwell Company, 1975), p. 117.

li. Leo Bogart, Cool Words, Cold War, Premises of Propaganda: Reassessing the USIA's Operating Assumptions in the Cold War (University Press of America; 2nd Revised edition, 1995), p. xxxv.

lii. Ibidem.

liii. Anthony Haigh, Cultural Diplomacy in Europe (New York: Manhattan Pub. Co, 1974), p. 77.

liv. Frances Stonor Saunders, The Cultural Cold War, p. 21.

lv. Ibidem.

lvi. Clipping, Paris Presse, June 29, 1950, signed Andre Varnod, Dossier d'artiste Martha Graham, Bibliothèque-musée de l'Opéra Collections, Paris.

lvii. Clipping, Le Parisien Libre, Dossier d'artiste Martha Graham, Bibliothèque-musée de l'Opéra Collections, Paris; also see "On the Debut of Martha Graham in Paris," Dance Magazine, August 1950, p. 10.

lviii. Clipping, Le Parisien Libre, Dossier d'artiste Martha Graham, Bibliothèque-musée de l'Opéra Collections, Paris.

lix. His alleged collaboration with the Nazi was loudly disapproved by the American audience and the press.

lx. Telegram, David Bruce to Dean Acheson, June 15, 1950, NND852916, RG 59, Box 2386, National Archives at College Park, College Park, MA.

lxi. Telegram, Dean Acheson to David Bruce, June 20, 1950, NND852916, RG 59, Box 2386, National Archives at College Park, College Park, MA .

lxii. Camelia Lenart, "Rehearsing and Transforming Cultural Diplomacy: Martha Graham's Tours to Europe during the Fifties," published in the Proceedings of Dance History Scholars Conference, October 2013.

lxiii. Ibidem.

lxiv. Tony Judt, Postwar: A History of Europe Since 1945 (Penguin, 2005), p. 77.

1xv. Serge Guilbaut, How New York Stole the Idea of Modern Art. Abstract Expressionism, Freedom, and the Cold War (Chicago: The University of Chicago Press, 1983), p. 5.

lxvi. 1947 the American Academy of Arts and Letters hosted a retrospective featuring nearly 200 of his works. In 1944, he was elected into the National Academy of Design as an Associate Academician. In the summer of 1949 , he was one of 250 sculptors who exhibited in the 3rd Sculpture International held at the Philadelphia Museum of Art.

lxvii. “My Day" June 30,1950, https://www.gwu.edu/ erpapers/myday/browsebyyear.cfm; accessed March 2016. 
lxviii. Marian Anderson, My Lord, What a Morning: An Autobiography, University of Illinois Press; Reprint edition, 2002.

lxix. Mollie Sommerville, Eleanor Roosevelt. As I knew Her (McLean: EPM Publications, 1996).p. 98; due to her mother's poor health Juliana was a regent since 1947, and became a queen on 4 May 1948; see Eleanor Roosevelt, The Autobiography of Eleanor Roosevelt (New York: Da Capo, 1992),p. 199; see William Hoffman, Queen Juliana, The Story of the Richest Woman in the World (New York: Harcourt Brace Jovanovich, 1979), p. 94.

lxx. William Hoffman, Queen Juliana, p. 11; During the official visits to the States the queen and her husband always visited regions from New York State which still had a rich Dutch heritage.

lxxi. State Department's Program of Queen Juliana's Visit in the USA, 1952, box 24950, M. Buitenlandse Zaken, 1945-1954, Nationaal Archief, The Hague.

lxxii. Letter to Baron DeVos van Steenwijk, the Consulate General of the Netherlands in New York, box 24948, M. Buitenlandse Zaken, 1945-1954, Nationaal Archief, The Hague.

lxxiii. Camelia Lenart, “Dancing Art and Politics beyond the Iron Curtain: Martha Graham's 1962 Tour to Yugoslavia and Poland," Dance Chronicle,vol. 39, no. 2 (2016), p. 197-217.

lxxiv. Ibidem.

\section{ABSTRACTS}

The article analyzes Eleanor Roosevelt's intricate and innovative relationship with American arts during a time when Americans did not believe yet in the power of the arts in making (and unmaking) political and diplomatic statements. Focusing on the collaboration between the First Lady and the modern dancer Martha Graham, it also proves that their partnership and its valuable and long lasting outcomes qualify them as pioneers of American cultural diplomacy. As the article shows, Roosevelt invited Martha Graham to perform "American Document" at the White House when the USA was contemplating its entrance in the Second World War. Like in the case of Marion Anderson's invitation, Graham's performance of modernism and patriotism was by no means a social event, but a conscientious decision to use the arts in the service of politics and diplomacy. The article follows Roosevelt's visionary involvement in the inception of American cultural diplomacy during the early fifties, when the former First Lady, now a recognized politician and savvy diplomat on her own, used her prestige and connections in helping Graham during her tours in Europe. Accompanied by the American Ambassador David Bruce, Roosevelt attended Graham's opening night in Paris, during the dancer's difficult first European tour in 1950. Subsequently, when Roosevelt's old friend, Queen Juliana of the Netherlands, visited Hyde Park in 1952, she orchestrated the Queen's meeting with Graham in New York City. On the occasion of Graham's second European tour, in 1954, the Queen attended one of her performances, which was an unprecedented diplomatic and audience success for the dancer and American diplomacy in Europe. Based on research in archives, as well as public and private collections from the USA, The Netherlands, Britain and France, the article is not only a historical reconstruction of a special collaboration, but also an homage to the two fascinating First Ladies - of politics and dance - who pioneered American cultural diplomacy. 
INDEX

Keywords: American Cultural Diplomacy, Eleanor Roosevelt, Martha Graham

\section{AUTHOR}

\section{CAMELIA LENART}

University at Albany, SUNY 